\title{
ERRATUM ARTICLE: Discursive hybridization and differentiation between Kleinism and Lacanism (Uruguay, 1955-1982)
}

Rev. Latinoam. Psicopat. Fund., São Paulo, 22(4), 884-908, dez. 2019

On pages 884 and 908

Where it reads

Gonzalo Grau Pérez*2

Gonzalo Grau Pérez

Read on

Gonzalo Grau-Pérez*2

Gonzalo Grau-Pérez

Editors: Profa. Dra. Ana Maria Rudge

This is an open-access article, which permits unrestricted use, distribution, 